\title{
GAMBARAN WORK-LIFE BALANCE PADA PASUKAN PENJAGA PERDAMAIAN INDONESIA: STUDI KUALITATIF
}

\author{
Freddy A. R. Simanjuntak ${ }^{1}$, Retno Hanggarani Ninin ${ }^{2}$ \\ ${ }^{1,2}$ Fakultas Psikologi, Universitas Padjadjaran \\ Jl. Raya Bandung-Sumedang KM.21 Kabupaten Sumedang, Jawa Barat 45363 \\ E-mail: freddy18003@mail.unpad.ac.id
}

\begin{abstract}
ABSTRAK
Selain bertugas sebagai pasukan yang menengahi konflik, pasukan penjaga perdamaian (peacekeeper) Indonesia yang disebut dengan Kontingen Garuda juga berperan sebagai individu yang juga berhadapan dengan kehidupan pribadinya. Kedua peran tersebut menuntut kinerja yang seimbang, karena ketidakseimbangan dapat menyebabkan salah satunya menjadi "korban", dalam pengertian tidak optimal dalam menjalankan perannya. Keseimbangan antara pekerjaan dengan kehidupan pribadi atau work-life balance, diperlukan agar seseorang dapat menyeimbangkan antara pekerjaan dan aktivitas lain di luar pekerjaan. Tujuan penelitian ini adalah untuk mengetahui gambaran keseimbangan tersebut pada para prajurit penjaga perdamaian Indonesia yang ditinjau dari perspektif konseptual work-life balance. Penelitian ini diharapkan dapat memberikan sumbangsih dalam keilmuan psikologi, khususnya yang berkaitan dengan work-life balance pada konteks kerja kemiliteran. Penelitian ini menggunakan pendekatan kualitatif dengan teknik purposive sampling, melibatkan 2 orang anggota peacekeeper Indonesia yang berusia 30 tahun dan 33 tahun. Data diperoleh menggunakaan wawancara mendalam (in depth interview) dan semi terstruktur. Hasil penelitian menunjukkan bahwa dari empat dimensi work-life balance, dua di antaranya menunjukkan tercapainya keseimbangan. Dimensi yang belum seimbang yaitu WIPL (Work Interference with Personal Life) dan WEPL (Work Enchancement of Personal Life). Dengan demikian, partisipan belum optimal dalam mengembangkan work-life balance pada dirinya dikarenakan jenis pekerjaan yang diemban menuntut kesiapsiagaan penuh karena berada di daerah konflik, sehingga sulit membagi peran yang proporsional dalam hal pekerjaan dan kehidupan pribadi.
\end{abstract}

Kata kunci: kontingen garuda; studi kualitatif; penjaga perdamaian; work-life balance

\begin{abstract}
While serving as force that mediate conflict, Indonesian Peacekeeper called Garuda Contingent also act as an individual who must deal with his personal life. Both roles must have a balanced performance, because imbalance can cause one of them to become a "victim", that it is not optimal in carrying out its role. Work-life balance was needed so that someone can balance work and other activities outside of work. The purpose of this study to find out how was the work-life balance for peacekeepers from it is conceptual perspective. The aim of this research was to develop a psychological theory that related to the concept of work-life balance of Indonesian peacekeepers. This study used a qualitative method with purposive sampling technique, involving 2 members of Indonesian peacekeeper aged 30 years and 33 years. The data were obtained using in-depth interview and semi-structured. The results showed that from four dimensions of work-life balance, the subjects were not able to balance the dimension of WIPL (Work Interference with Personal Life) and WEPL (Work Enchacement of Personal Life). Thus, the subject had not been able to optimally develop a work-life balance because their job required full preparedness because in a conflict area, so it was difficult to divide proportional roles in terms of work and personal life.
\end{abstract}

Keywords: garuda contingent; qualitative study; peacekeeper, work-life balance 


\section{PENDAHULUAN}

Permasalahan work-life balance menjadi suatu hal yang sangat penting bagi kebahagiaan psikologis individu yang ditandai dengan kepercayaan diri yang tinggi, kepuasan, dan berbagai harmonisasi yang dirasakan dalam kehidupan. Hal ini dapat dianggap sebagai indikator kesuksesan peran dalam kehidupan kerja dan keluarga (Clarke, Koch, \& Hill, 2004). Worklife balance dapat dipengaruhi oleh faktor internal atau faktor eksternal, baik dalam keluarga maupun organisasi. Berdasarkan kajian literatur, yang termasuk faktor internal adalah kepribadian (Bulgan, 2011; Valcour, 2007; Wierda-Boer, Gerris, \& Vermulest, 2008) dan komitmen terhadap peran (Beutell, 2007; Helmle, 2010;). Adapun faktor eksternal adalah keberadaan anak (Greenhouse, Ziegert, \& Allen, 2011; Handayani, Afiatin, \& Adiati, 2015), dukungan keluarga (Eddleston \& Powell, 2012; Greenhouse dkk., 2011), serta tuntutan keluarga (Ellwart \& Kondradt, 2011).

Work-life balance sendiri merupakan kondisi ketika individu mampu secara optimal berkomitmen dalam pekerjaan dan juga keluarga, serta bertanggung jawab dengan baik dalam kegiatan non-pekerjaan (Parkes \& Langford, 2008). Work-life balance dapat diartikan pula sebagai pemenuhan harapan terkait peran yang dinegosiasikan dan dibagi antara individu dengan pasangannya, meliputi peran dalam ranah pekerjaan dan domain keluarga (Grzywacz \& Carlson, 2007). Fisher-McAuley, Stanton, Jolton, \& Gavin (2003) mendefinisikan work-life balance sebagai hal yang dilakukan seseorang dalam membagi waktu antara bekerja di luar tempat kerja dan aktivitas lain di luar pekerjaan, yang di dalamnya melibatkan pilihan individu, sehingga berpotensi untuk menjadi sumber konflik intrapersonal.

Adapun dimensi dari work-life balance menurut Fisher, Bulger, dan Smith (2009), yaitu: a) WIPL (Work Interference with Personal Life), mengacu pada sejauh mana pekerjaan dapat mengganggu kehidupan pribadi individu; b) PLIW (Personal Life Interference with Work), mengacu pada sejauh mana kehidupan pribadi individu mengganggu kehidupan pekerjaannya; c) PLEW (Personal Life Enhancement of Work), mengacu pada sejauh mana kehidupan pribadi seseorang dapat meningkatkan performa individu dalam dunia kerja; dan d) WEPL (Work Enhancement of
Personal Life), mengacu pada sejauh mana pekerjaan dapat meningkatkan kualitas kehidupan pribadi individu.

Sebuah penelitian di Inggris menyatakan bahwa work-life balance adalah penyebab dari munculnya stres pada pekerjaan dengan koefisien reliabilitas 0,748 (Society, 2001). Alat ukur stres yang dikembangkan di University of Manchester bernama ASSET (A Shortened Stress Evaluation Tool) menyatakan bahwa work-life balance merupakan salah satu aspek yang menjadi penyebab dari stres (Faragher, Cooper, \& Cartwright, 2004). Beberapa penelitian menyatakan bahwa terdapat korelasi negatif antara work-life balance dengan tingkat stres kerja (Grant-Vallone and Donaldson, 2010; Yang et al., 2018; Kotera et al., 2019), dan menurut survei yang dilakukan oleh stasiun televisi Consumer News and Business Channel (CNBC), salah satu pekerjaan yang memiliki tingkat stres paling tinggi adalah militer (CNBC, 2017). Hal ini sejalan dengan penelitian Kartini, Zakiyah, \& Narulita (2018) yang menemukan bahwa prajurit TNI Angkatan Darat memiliki tingkat stres berat dan mekanisme koping yang cenderung destruktif. Work-life balance di dunia militer merupakan suatu faktor psikologis yang penting dalam menjelaskan keseimbangan antara kehidupan militer dan kehidupan di luar pekerjaan. Keseimbangan kedua faktor ini secara positif dapat memengaruhi kebahagiaan. Namun, Dehigala (2015) menyatakan ketika seseorang berpikir negatif, maka akan teraktivasi konflik antara tempat kerja dan kehidupan pribadi atau keluarga. Tentara memang pada umumnya dilatih untuk kuat secara fisik dan mental, namun kehidupan di tempat kerja dan kehidupan keluarga secara potensial tetaplah memiliki pengaruh yang besar bagi setiap orang, baik positif maupun negatif (Dehigala, 2015).

Di Indonesia, Tentara Nasional Indonesia (TNI) merupakan militer dan angkatan perang yang terdiri dari Angkatan Darat (AD), Angkatan Laut (AL), dan Angkatan Udara (AU). Salah satu tugas TNI sesuai Undang-Undang Nomor 34 Tahun 2004 Pasal 7 tentang TNI adalah melaksanakan tugas perdamaian dunia sesuai dengan kebijakan politik luar negeri (Lolombulan, 2015). TNI merupakan salah satu unsur militer yang rutin tergabung dalam misi pasukan penjaga perdamaian (peacekeeper) di bawah bendera Perserikatan Bangsa-Bangsa (PBB) dengan sebutan Kontingen Garuda. Kontingen Garuda memiliki tugas dan kewajiban untuk menengahi konflik yang terjadi dengan melakukan 
negosiasi, mediasi, arbitrasi atau cara-cara lain untuk menyelesaikan konflik antara pihak-pihak yang bertikai (Yamasitha, 2008). Prajurit dalam Kontingen Garuda Indonesia merupakan komponen militer pada misi perdamaian PBB yang diberi kewenangan untuk melindungi dirinya sendiri serta penduduk sipil di bawah perlindungannya (Bellamy \& Williams, 2004), sehingga walaupun mereka melaksanakan tugastugas perdamaian, mereka tetap dipersenjatai dan bertindak seolah-olah sedang menghadapi perang (Lacey, 2005).

Tentu para prajurit TNI yang bertugas tersebut memiliki kehidupan pribadi sebagaimana setiap orang pada umumnya. Tekanan fisik serta psikologis yang ada dalam pekerjaan dalam konteks menjalankan misi perdamaian tersebut, dengan keharusan untuk bertugas jauh dari Indonesia, tidak diperbolehkan membawa keluarga, dan risiko terkait keselamatan, akan berdampak pada kehidupan pribadi mereka. Waktu dan tenaga yang banyak dihabiskan untuk memenuhi tugas dan tanggung jawab pekerjaan, dapat berpeluang untuk memengaruhi pemenuhan tugas dan tanggung jawab di luar pekerjaan, seperti keluarga, diri sendiri, atau kehidupan sosialnya. Ketika pekerjaan sudah masuk atau tercampur dengan kehidupan, maka work-life balance atau keseimbangan antara kehidupan dan juga pekerjaan dapat terganggu (Fisher, Bulger, \& Smith, 2009). Hasil survei terhadap tentara Kanada (Canadian Force) dan keluarganya menyatakan bahwa work-life balance merupakan sebuah masalah dan mereka memiliki keinginan untuk meningkatkan work-life balance (Jefferies, 2001a). Sebagian besar penelitian yang telah dilakukan menunjukkan bahwa terdapat konflik kerjakeluarga, khususnya konflik kerja terhadap kehidupan yang tinggi, sehingga mengakibatkan adanya keinginan untuk keluar dari pekerjaan sebagai tentara Kanada tersebut (Dowden, 2001a). Penelitian lain pada partisipan tantara Kanada juga menunjukkan bahwa work-life balance berhubungan dengan keputusan mereka untuk bertahan atau keluar dari kedinasan militer (Pickering, 2006).

Selain itu, penelitian terhadap tentara Inggris (UK Armed Forces) menyatakan bahwa alasan utama dari berkurangnya work-life balance adalah gaya hidup militer (penempatan reguler, perpindahan dan tugas operasi), level dari tentara saat ini, serta kurangnya sumber daya. Hambatan untuk mendapatkan work-life balance yang baik tidak hanya karena gaya hidup militer, tetapi juga karena budaya organisasi yang ada. Ketidakmampuan untuk merencanakan pendidikan anak, kesulitan untuk memasukkan anak ke sekolah yang baik, serta hambatan untuk karier pasangan sebagai akibat dari gaya hidup militer, merupakan sumber frustrasi utama tentara. Banyak tentara yang melaporkan harus mengandalkan orang lain untuk mengelola tanggung jawab pekerjaan dan non-pekerjaan (Fisher, Lyonette, Barnes, \& Newell, 2015).

Penelitian yang telah dilakukan di Indonesia untuk melihat gambaran work-life balance pada personel militer wanita TNI AU (Wara) menunjukkan bahwa terdapat ketidakseimbangan proporsi waktu, tenaga, dan komitmen antara kehidupan pekerjaan dan kehidupan di luar pekerjaan pada para prajurit Wara. Upaya untuk merekonsiliasi work-life balance di berbagai domain kehidupan personel militer tersebut adalah melalui komunikasi dengan pimpinan maupun dengan suami, menetapkan batasan, dan menyediakan waktu luang. Tercapainya work-life balance pada prajurit Wara ternyata dipengaruhi oleh kepemimpinan atasan dan dukungan suami (Atmaningrum, 2018). Penelitian lain dengan bahasan yang sama menunjukkan bahwa terdapat pengaruh work-life balance yang positif dan signifikan terhadap work-engagement pada prajurit TNI (Pratiwi, 2019).

Kontingen Garuda sebagai prajurit penjaga perdamaian yang merupakan bagian dari organisasi yang besar, tentu tidak bisa lepas dari situasi ketika pekerjaan yang digelutinya dipengaruhi oleh faktor-faktor non-pekerjaan, seperti keluarga, persahabatan, dan sebagainya. Observasi peneliti sebagai seseorang yang bekerja dalam konteks militer menghasilkan temuan bahwa work-life balace memberikan dampak psikologis pada prajurit TNI dalam Kontingen Garuda, sehingga diperlukan penelitian untuk mengonfirmasi temuan tersebut, karena apabila work-life balance rendah, maka motivasi serta kinerja secara umum dari para prajurit penjaga perdamaian dapat terhambat optimalisasinya. Dikarenakan work-life balance pun merupakan bagian dari psikologi positif (Morganson, Litano, \& O’Neill, 2014), hasil penelitian ini juga akan dapat berguna untuk diaplikasikan di bidang psikologi militer, serta memegang kunci untuk pengembangan strategi Sumber Daya Manusia (SDM) dan pengelolaan organisasi. Oleh karena itu, peneliti tertarik untuk melihat bagaimana gambaran dari work-life 
balance pada Pasukan Penjaga Perdamaian (peacekeeper) Kontingen Garuda Indonesia, khususnya pada level pangkat Perwira Pertama yang telah berkeluarga. Hal ini dikarenakan mereka merupakan level pimpinan yang tidak hanya bertanggung jawab atas tugas dan jabatannya sendiri, melainkan pula bertanggung jawab atas tugas anggota yang berada di bawah kepemimpinannya.

\section{METODE}

Penelitian ini bersifat deskriptif, yaitu mendeskripsikan atau memberi gambaran terhadap objek yang diteliti melalui data atau sampel yang telah terkumpul, kemudian melakukan analisis dan membuat kesimpulan yang berlaku untuk umum (Sugiyono, 2009). Partisipan penelitian merupakan sumber data utama. Dalam penelitian ini partisipan dipilih secara purposive, yaitu teknik pemilihan sampel berdasarkan kriteria tertentu (Poerwandari, 2001). Adapun kriteria partisipan dalam penelitian ini yaitu prajurit dengan level perwira pertama, menikah, laki-laki, dan telah menyelesaikan tugas misinya sebagai bagian dari pasukan penjaga perdamaian. Diperoleh dua orang prajurit yang bersedia menjadi partisipan. Mereka telah bertugas sebagai pasukan perdamaian PBB di Afrika, serta merupakan partisipan yang ada dan berdomisili di wilayah yang sama dengan peneliti untuk kepentingan teknis pengambilan data secara tatap muka di luar jaringan.

Teknik pengumpulan data adalah dengan wawancara semi-terstruktur, dengan pedoman yang disusun secara sistematis berdasarkan konsep work-life balance menurut Fisher, Bulger, \& Smith (2009). Wawancara termasuk dalam kategori indepth interview (wawancara mendalam) yang pelaksanaannya lebih bebas serta terbuka dengan meminta pendapat dan ide-ide dari partisipan. Selain itu, wawancara dilakukan agar peneliti mendapat data yang valid dan dapat dipertanggungjawabkan. Adapun panduan wawancara dalam penelitian ini tercantum di Tabel 1.

Pengolahan data menggunakan metode coding mengacu pada ke-4 dimensi work-life balance, yaitu: WIPL (Work Interference with Personal Life), PLIW (Personal Life Interference with Work), PLEW (Personal Life Enhancement of Work), dan WEPL (Work Enhancement of Personal Life). Coding dimaksudkan untuk dapat mengorganisasikan dan mengurutkan data
Tabel 1. Daftar Pertanyaan dalam Wawancara

\begin{tabular}{lr}
\hline \multicolumn{1}{c}{ Dimensi } & \multicolumn{1}{c}{ Butir Pertanyaan } \\
\hline $\begin{array}{l}\text { 1. Work } \\
\text { Interference }\end{array}$ with Personal & 1. $\begin{array}{l}\text { Setelah pulang kerja seharian, } \\
\text { bagaimana Anda melakukan } \\
\text { Life (WIPL) }\end{array}$ \\
2. & $\begin{array}{l}\text { Berkaitan pribadi lainnya? } \\
\text { bagaimana relasi Anda dengan } \\
\text { teman-teman? }\end{array}$ \\
3. & $\begin{array}{l}\text { Apakah karena pekerjaan ini } \\
\text { menyulitkan Anda untuk berelasi } \\
\text { dengan teman-teman? } \\
\text { Berkaitan dengan pekerjaan Anda, } \\
\text { bagaimana dengan kehidupan } \\
\text { pribadi Anda? }\end{array}$
\end{tabular}

5. Bagaimana dengan waktu kerja yang diberikan kepada Anda? Bisakah Anda jelaskan kualitas kehidupan Anda apakah terganggu dengan waktu kerja Anda?

2. Personal Life 6. Bagaimana dengan kehidupan Interference with Work (PLIW)

3. Personal Life
Enchancement
of Work
(PLEW)

4. Work
enhancement of
personal life
(WEPL)
Anda saat bertugas, sejauhmana kehidupan pribadi Anda menguras energi sehingga tidak dapat bekerja dengan baik?

7. Sejauhmana pekerjaan Anda sering terganggu karena urusan pribadi?

8. Bagaimana dengan urusan pribadi Anda, apakah sampai menyulitkan Anda untuk bekerja?

9. Sejauhmana kehidupan pribadi Anda menyulitkan Anda untuk fokus dalam bekerja?

10. Saat sedang bekerja, bagaimana cara yang Anda lakukan agar maksimal dalam bekerja?

11. Bisa Anda ceritakan bagaimanakah kehidupan pribadi Anda mendukung pekerjaan Anda?

12. Coba Anda ceritakan bagaimanakah kehidupan pribadi Anda bisa memberi energi untuk bekerja!

13. Apakah kehidupan pribadi Anda membantu sekaligus memberikan semangat bagi Anda untuk pekerjaan di hari berikutnya?

14. Apakah pekerjaan Anda memberikan energi untuk melakukan aktivitas pribadi di luar pekerjaan lainnya?

15. Bagaimana suasana hati Anda saat kembali ke barak, sepulang melaksanakan tugas harian?

16. Apakah hal-hal yang Anda lakukan di tempat kerja membantu untuk menangani masalah pribadi dan urusan sehari-hari? Coba ceritakan! 
berdasarkan kerangka konseptualnya. Kredibilitas dalam penelitian ini dilakukan dengan triangulasi, member checking, dan meningkatkan ketekunan. Triangulasi yang digunakan adalah triangulasi teknik, yaitu dengan menggabungkan wawancara mendalam, observasi dan beberapa dokumentasi mengenai partisipan yang diakses melalui jalur intra-office sesuai kewenangan peneliti dan persetujuan dari kedua partisipan. Member checking digunakan setelah pengumpulan data selesai untuk mendapatkan kesepakatan berkenaan dengan akurasi informasi yang terdapat di dalam datanya. Selain itu peneliti juga meningkatkan ketekunan dengan melakukan pengamatan secara lebih cermat terhadap hasil di lapangan dengan teori yang digunakan.

Dalam melakukan analisis, penelitian ini merujuk pada Miles \& Huberman (1992), yaitu dilakukan dengan cara: a) reduksi, yaitu merangkum, memilih hal-hal pokok, dan memfokuskan pada hal-hal penting sehingga data yang direduksi akan memberikan gambaran yang lebih jelas; b) penyajian data, yaitu menyajikan data dalam bentuk teks yang bersifat naratif. Data disajikan dengan melakukan pengelompokan sesuai dengan dimensi masing-masing; c) penarikan kesimpulan, yaitu setelah menjabarkan berbagai data yang telah diperoleh, peneliti membuat kesimpulan yang merupakan hasil dari suatu penelitian.

Penelitian yang baik dicirikan oleh autentisitas (authenticity) dan kepercayaan (trustworthiness) yang merupakan konsep sentral bagi keseluruhan proses riset (Daymon \& Holloway, 2008). Autentisitas dan kepercayaan diperlihatkan dalam penelitian ini melalui pendokumentasian proses riset dan keputusan-keputusan yang dibuat oleh peneliti selama riset dilakukan bersama dengan supervisor yang menjadi second coder sekaligus penulis kedua dalam artikel ini.

\section{HASIL DAN PEMBAHASAN}

Partisipan penelitian adalah A, laki-laki, menikah, pangkat kapten, usia 33 tahun; dan B, laki-laki, menikah, pangkat letnan, usia 30 tahun. Pembahasan penelitian difokuskan pada tinjauan terhadap dimensi-dimensi work-life balance menurut Fisher, Bulger, \& Smith (2009), yaitu: WIPL (Work Interference with Personal Life), PLIW (Personal Life Interference with Work), PLEW (Personal Life Enhancement of Work), dan WEPL (Work Enhancement of Personal Life).
Dimensi WIPL (Work Interference with Personal Life)

Dimensi ini mengacu pada sejauh mana pekerjaan dapat mengganggu kehidupan pribadi individu. Misalnya, bekerja dapat membuat seseorang sulit mengatur waktu untuk kehidupan pribadinya. Berdasarkan wawancara yang dilakukan kepada partisipan B, ia merasa aktivitas pribadinya ada yang masih bisa dilakukan dan ada pula yang sulit dilakukan. Yang masih bisa dilakukan angtara lain kegiatan lari (jogging), main sepak bola, basket, juga bermain ke PX (kantin), mendatangi barak kompi, bertemu dengan temanteman dan anggota, melaksanakan kegiatan memasak dan menikmati masakan Indonesia seperti nasi goreng, nasi kikil, ikan teri, cumi, dan lain-lain, yang sebenarnya cukup sulit didapatkan di Afrika. Sedangkan kegiatan pribadi atau "me time" yang sulit dilakukan antara lain membaca buku. Hal itu terjadi karena sambil membaca buku ia juga stand by untuk melakukan telepon dengan keluarganya di Indonesia, sebagaimana dikomunikasikan oleh partisipan B sebagai berikut.

\section{"Saya diberi pinjaman buku oleh rekan dari negara Pakistan, untuk menyelesaikan membaca bukunya bisa sampai berbulan-bulan. Malam sering juga terima telepon. Sering stand by telepon. Jadi 'me time' sering terganggu. Hampir tiap hari, kehidupan pribadi jadi terbatas."}

Dalam hal kehidupan keluarga, partisipan B mengatakan bahwa sumber hambatan utama adalah adanya perbedaan waktu empat jam antara Afrika dan Indonesia, yang menyulitkannya untuk menentukan waktu yang sesuai untuk melakukan komunikasi. Partisipan B mengatakan harus menyesuaikan dengan waktu di Indonesia, dan terkadang waktunya tidak cocok. Pada saat partisipan sedang istirahat dan mencoba berkomunikasi lewat telepon, istri partisipan juga sedang bekerja di Rumah Sakit, sehingga kurang leluasa untuk berkomunikasi. Demikian pula sebaliknya di saat istri menghubungi, kondisi partisipan seringkali sedang bekerja dan tidak bisa berkomunikasi dengan leluasa.

Partisipan A cenderung berfokus pada kegiatan pekerjaan yang ia rasakan penuh dari pagi sampai dengan sore. Selesai bertugas sekitar jam 6 sore lalu dilanjutkan dengan kegiatan ibadah, kemudian briefing, dan baru bisa pulang ke barak sekitar jam 
10 malam. Namun demikian, partisipan A mengatakan bahwa aktivitas pribadinya masih bisa dilakukan, namun ia menggunakan istilah "mencuri-curi waktu" untuk bisa melakukannya. Misalnya, mengunjungi PX (kantin), bermain band, bermain karambol, catur, olah raga, kegiatan fitness/gym, bermain playstation (PS) bersama anggota, dan lain-lain.

Partisipan A mengatakan bahwa sebenarnya aktivitas pribadi terganggu, karena selama bertugas sebagai penjaga perdamaian, bahkan saat tidur Handy Talky (HT) harus dalam posisi stand by (on call). Dalam hal perannya terhadap keluarga, partisipan A juga merasakan adanya kendala yang bersumber dari jauhnya jarak dengan keluarga. Hubungan dengan istri menjadi nomor 2 (dua) atau 3 (tiga). Komunikasi dengan istri sering terkendala juga karena adanya perbedaan waktu AfrikaIndonesia. Namun, partisipan A mengatakan ia menghargai pekerjaannya karena membuatnya dapat menyalurkan energinya, artinya dengan adanya pekerjaan, tension yang dirasakannya menjadi berkurang. Namun, partisipan A menambahkan, jika benar-benar sedang kosong, maka akan muncul tension lagi dalam dirinya dan akan kepikiran keluarga.

Berdasarkan pendapat Fisher, Bulger, dan Smith (2009) bahwa work-life balance dapat diukur dari sejauh mana pekerjaan dapat mengganggu kehidupan pribadi individu, maka dalam hal ini, partisipan B dan A menghayati adanya pengaruh pekerjaan dalam kehidupan pribadinya khususnya dalam konteks kehidupan berkeluarga. Partisipan B dan A memiliki situasi pekerjaan yang sama yaitu waktu kerja penuh dan bahkan sampai malam hari, serta saat usai bekerja harus siap bila ada hal-hal yang tidak terduga, sehingga Handy Talkie (HT) dan telepon harus dalam keadaan stand by (on call). Hal ini berdampak pada keadaan di mana kedua partisipan tidak dapat menjalani kehidupan pribadi atau kehidupan non-pekerjaannya secara optimal.

Bila dikaitkan dengan dimensi WIPL, maka keadaan tersebut mengakibatkan situasi di mana pekerjaan yang dimiliki dapat mengganggu kehidupan pribadinya. Sifat pekerjaan yang menuntut kesiapsiagaan penuh tampaknya menjadi faktor utama yang menyebabkan hal tersebut, selaras dengan apa yang disampaikan oleh Lacey (2005) bahwa meski para prajurit melaksanakan tugas-tugas perdamaian, mereka tetap dipersenjatai dan bertindak seolah-olah sedang menghadapi perang. Jika pekerjaan sebagai pasukan penjaga perdamaian menganggu kehidupan pribadi prajurit pada level yang tinggi, maka dapat mengakibatkan apa yang disebut dengan peacekeeping stress (Thomas \& Castro, 2003). Pengaruh stres para personel militer itu akan berdampak pada kemampuan mereka untuk menyelesaikan misi dengan sukses (Kavanagh, 2005).

\section{Dimensi PLIW (Personal Life Interference with Work)}

Dimensi ini mengacu pada sejauh mana kehidupan pribadi individu mengganggu kehidupan pekerjaannya. Berdasarkan hasil wawancara yang dilakukan pada partisipan $\mathrm{B}$, ia menyatakan bahwa kehidupan pribadi partisipan tidak mengganggu pekerjaannya, karena ia merasa bahwa pekerjaannya tidak melibatkan aktivitas fisik yang melelahkan. Ia pun bisa lebih bisa fokus terhadap pekerjaannya dalam misi dibandingkan jika bertugas di dalam negeri. Hal ini dikarenakan partisipan berada pada tempat yang memang terisolasi di daerah gurun serta jauh dari keramaian, sehingga membuatnya tidak bisa bepergian ke tempat lain dan bisa lebih fokus dalam bekerja. Partisipan B juga merasa bahwa kehidupan pribadi yang dialami di daerah tugas tidak terlalu menyulitkan pekerjaannya sehari-hari, demikian juga dengan kehidupan pribadi dalam konteks keluarga.

Hal tersebut serupa dengan pernyataan partisipan A, bahwa kehidupan pribadinya tidak sampai menguras energi maupun membuatnya tidak dapat bekerja dengan baik. Partisipan merasa dapat bersikap profesional dalam bekerja dengan cara mengesampingkan permasalahan pribadi yang ada. Pengecualian untuk mengesampingkan pekerjaan adalah bila menyangkut konteks darurat keluarga, misalnya orang tua sakit. Urusan mendesak yang terjadi dalam keluarga bisa sedikit memecah konsentrasinya, namun tidak sampai menyulitkannya untuk bekerja. Selain itu, cara kerja partisipan A yang memiliki target pencapaian tertentu dan menerapkan pola kerja dengan skala prioritas, membuat pekerjaannya tidak terpengaruh oleh kehidupan pribadinya.

Data di atas menunjukkan bahwa kedua partisipan tidak mengalami keadaan terganggu dalam hal pekerjaannya yang diakibatkan oleh kehidupan pribadinya. Partisipan dapat menunjukkan sikap yang bertanggung jawab dan berusaha profesional dalam setiap pekerjaannya, sejalan dengan hasil penelitian Pratiwi (2019) yang menemukan bahwa dimensi PLIW merupakan 
dimensi yang paling rendah kontribusinya dalam memengaruhi work-life balance.

\section{Dimensi PLEW (Personal Life Enhancement of Work)}

Dimensi ini mengacu pada sejauh mana kehidupan pribadi seseorang dapat meningkatkan performa individu dalam bekerja. Misalnya, apabila individu merasa senang oleh karena kehidupan pribadinya yang menyenangkan, maka akan dapat membuat suasana hati saat bekerja menjadi menyenangkan pula.

Berdasarkan jawaban wawancara terhadap partisipan B, kehidupan pribadi yang mendukungnya di daerah tugas adalah kesempatan untuk melakukan kegiatan olah raga rutin. Ia mengaku membutuhkannya untuk membuat kesehatannya terjaga dan dapat mendukung tugasnya. Kehidupan pribadi lain yang dapat memberinya energi untuk bekerja adalah saat ketika partisipan selesai berkomunikasi dengan anaknya yang ada di Indonesia. Komunikasi melalui telepon kepada istri maupun anak bisa memberikan semangat yang luar biasa kepadanya. Namun, B menyayangkan bahwa hal tersebut tidak dapat dilakukan setiap hari karena dibatasi oleh perbedaan zona waktu. Hal yang dapat dilakukannya adalah dengan saling berkirim foto atau video melalui media sosial kepada keluarganya, sehingga partisipan dapat bersemangat dalam melaksanakan pekerjaannya.

Pada partisipan A, kegiatan bermain, mencari teman, atau berkunjung ke teman-teman dari negara lain, seperti Pakistan, adalah kehidupan pribadi yang sangat mendukung pekerjaannya. Partisipan menganggap bahwa hubungan relasi yang baik dengan pasukan dari negara lain akan mendukung pekerjaannya yang terkadang membutuhkan koordinasi yang baik dengan negara lain. Partisipan A menambahkan bahwa dirinya memang senang berkumpul dan memiliki banyak teman yang dapat memberikan energi lebih banyak kepadanya. Partisipan A mengatakan pula bahwa di saat dirinya letih, maka ia akan memilih untuk mengobrol dan bercengkerama dengan rekanrekannya, sehingga energinya untu bekerja akan bertambah. Partisipan A cenderung menganggap dirinya adalah tipikal orang yang berusaha untuk mengakhiri hari dengan baik, sehingga keesokan hari, saat ia akan mulai bekerja, akan menjadi awal yang baik. Namun, tidak jarang pula ia memiliki masalah dengan rekan, keluarga, maupun istri pada malam hari yang dapat menurunkan mood-nya, sehingga menghabiskan energinya untuk bekerja.

Jika mengacu pada definisi dari dimensi ini, maka dukungan keluarga dan lingkungan kerja dalam hal ini berdampak positif pada tercapainya work-life balance, yakni membuat partisipan mampu bersemangat dan menambah energinya dalam bekerja, sehingga meningkatkan performanya dalam bekerja. Hal tersebut dapat menjadi faktor yang berpengaruh dalam meningkatkan performa prajurit dalam bekerja di daerah misi. Ini juga selaras dengan apa yang disampaikan oleh Schabracq, Winnubst, \& Cooper (2003), bahwa faktor-faktor yang dapat memengaruhi work-life balance adalah karakteristik keluarga, pekerjaan, dan sikap sebagai seorang prajurit pasukan perdamaian PBB.

\section{Dimensi WEPL (Work Enhancement of Personal Life)}

Dimensi ini mengacu pada sejauh mana pekerjaan dapat meningkatkan kualitas kehidupan pribadi individu, misalnya keterampilan yang diperoleh individu pada saat bekerja, bermanfaat untuk kehidupan sehari-hari. Berdasarkan hasil wawancara yang dilakukan, partisipan B menyatakan bahwa dirinya yang memiliki jabatan sebagai perwira penghubung (liaison officer) membuatnya memiliki banyak teman dan dapat membangun jaringan (network) dengan negara lain. Hal tersebut berdampak pada seringnya pasukan dari Nigeria dan Pakistan melakukan aktivitas olahraga bersama dengan pasukan dari Indonesia, seperti basket, voli, dan bulu tangkis. Meskipun demikian, partisipan B mengatakan bahwa dirinya seperti merasakan tidak adanya perbedaan antara di kantor saat bekerja dengan di barak, karena saat jam tidur pun ia harus selalu stand by (on call) bila suatu saat dipanggil oleh atasan. Partisipan B merasa tidak ada yang ia lakukan di tempat kerja yang bisa membantu dirinya dalam menangani kehidupan pribadinya. Dapat disimpulkan bahwa bagi partisipan B, faktor pekerjaan tidak berperan penting dalam peningkatan aspek-aspek tertentu di kehidupan pribadinya.

Sama seperti partisipan B, partisipan A juga mengatakan bahwa pekerjaan tidak ada sangkut pautnya dalam peningkatan kompetensi dalam melakukan aktivitas pribadi di luar pekerjaan. Ditambahkan pula bahwa pekerjaan yang dikerjakannya tidak sampai memengaruhi aktivitasnya di luar pekerjaan atau di luar jam 
dinas. Partisipan A juga mengatakan bahwa hal-hal yang ia lakukan di tempat kerja tidak selalu dapat membantu dirinya dalam menangani masalah pribadi atau urusan sehari-hari. Justru bantuan untuk menyelesaikan masalah sehari-harinya diperoleh dari rekan-rekan, anggota, maupun senior yang dekat dengan dirinya, terutama ketika ia sharing kepada rekan-rekannya dengan santai sambil bermain game.

Bila dimensi ini dikaitkan dengan faktor pekerjaan partisipan $\mathrm{B}$ dan $\mathrm{A}$, keduanya merasa belum menemukan hal yang dapat meningkatkan kehidupan pribadinya (penulis: selain yang bersumber dari faktor penghasilan). Hal tersebut dapat terjadi karena pekerjaan partisipan yang berhubungan dengan kompetensi "pertempuran" dan penugasan saat ini, yaitu situasi perang di wilayah konflik yang melibatkan tugas patroli serta upaya-upaya perdamaian di wilayah kerjanya. Seperti yang diketahui, hal ini relatif tidak berkaitan dengan kompetensi yang dibutuhkan dalam kehidupan pribadi partisipan sehari-hari. Oleh karena itu, faktor pekerjaan tidak sepenuhnya memberikan energi maupun semangat kepada partisipan dalam menjalani kehidupan pribadi. Justru, permasalahan dalam kehidupan pribadinya cenderung dapat diselesaikan bukan oleh pekerjaannya, tetapi oleh bantuan rekan-rekannya di militer.

\section{SIMPULAN}

Berdasarkan dimensi WIPL (Work Interference with Personal Life), pekerjaan kedua partisipan dapat mengganggu kehidupan pribadi, terutama berhubungan dengan tuntutan kesiapsiagaan penuh sepanjang waktu di daerah konflik. Berdasarkan dimensi PLIW (Personal Life Interference with Work) ditemukan bahwa kehidupan pribadi tidak mengganggu pekerjaan secara teknis, karena kedua partisipan jauh dari keluarga dan tidak ada peran teknis yang bisa mereka lakukan sebagai anggota keluarga. Selain itu, ini juga berkaitan dengan adanya rasa tanggung jawab yang dimiliki serta sikap yang profesional dalam melaksanakan setiap pekerjaan. Berdasarkan dimensi PLEW (Personal Life Enhancement of Work) ditemukan bahwa kehidupan pribadi dapat meningkatkan performa dalam pekerjaan. Hal ini dikaitkan dengan hadirnya dukung sosial dari lingkungan maupun keluarga yang berdampak positif sehingga menambah semangat serta energi dalam bekerja. Selain itu, karakteristik pribadi partisipan yang profesional dalam bekerja juga turut menstimulasi peningkatan performa kerja. Berdasarkan dimensi WEPL (Work Enhancement of Personal Life) ditemukan bahwa pekerjaan kedua partisipan belum dapat meningkatkan sejumlah aspek dalam kehidupan pribadi mereka. Hal tersebut dapat terjadi karena pekerjaan partisipan yang berhubungan dengan kompetensi "pertempuran" di wilayah konflik, relatif tidak berkaitan dengan kompetensi yang dibutuhkan dalam kehidupan pribadi.

Berdasarkan hasil pembahasan ke-4 dimensi work-life balance yang dijadikan acuan, dapat disimpulkan bahwa kedua partisipan belum mampu secara optimal untuk mengembangkan work-life balance pada dirinya, terutama pada dimensi WIPL (Work Interference with Personal Life) dan WEPL (Work Enchacement of Personal Life). Hal ini dapat dikarenakan jenis pekerjaan yang diemban, yakni tentara, cenderung menuntut kesiapsiagaan penuh di daerah konflik, sehingga membuat kedua partisipan cenderung sulit untuk membagi peran yang proporsional dalam hal pekerjaan dan kehidupan pribadi (non-pekerjaan).

Keterbatasan penelitian ini adalah adanya subjektivitas yang ada pada peneliti. Penelitian ini sangat tergantung kepada interpretasi peneliti tentang makna yang tersirat dalam wawancara, sehingga kemungkinan bias masih tetap ada. Untuk mengurangi bias tersebut, maka dapat dilakukan proses triangulasi yang lebih detail. Saran untuk penelitian selanjutnya adalah penelitian sejenis dengan menggunakan metode kuantitatif yang dapat menggunakan sampel yang lebih banyak, sehingga dapat dilakukan generalisasi terhadap hasil penelitian.

\section{DAFTAR PUSTAKA}

Atmaningrum, A. (2018). Work-life Balance Pada Wanita Angkatan Udara Indonesia (Wara). Yogyakarta, DI Yogyakarta, Indonesia: Universitas Gajah Mada.

Bellamy, A. J., \& Williams, P. (2004). Introduction: Thinking A New about Peace. International Peacekeeping, 1-15.

Beutell, N. J. (2007). Self-employment, workfamily conflict, and work-family synergy: Antecedents and consequences. Journal of Small Business and Entrepreneurship, 20(4), 325-344

Bulgan, G. (2011). Work family balance and psychososial adjustment of International 
students. Indiana, USA: Purdue University.

Clarke, M., Koch, L., \& Hill. (2004). The workFamily Interface: Differentiating Balance and Fit. Family and Consumer Sciences Research Journal, 33.

CNBC. (2017, January 12). The 10 most stressful jobs in America. Retrieved from CNBC.com:

https://www.cnbc.com/2017/01/11/moststressful-jobs-in-america.html

Daymon, C., \& Holloway, I. (2008). Metodemetode Riset Kualitatif: dalam Public Relations dan Marketing Communications. Yogyakarta: Penerbit Bentang.

Dehigala, R. (2015). Study on the Relationship Between Work Family Balance and Happiness of Soldiers in Sri Lanka Army. Srilanka: University of Kelaniya.

Dowden, C. (2001a). Quality of life in the Canadian Forces: Results from the National Survey. Toronto: Defence R\&D Canada.

Ellwart, T., \& Konradt, U. (2011). Formative versus reflective measurement: An illustration using work-family balance. The Journal of Psychology, 145(5), 391417.

Faragher, E. B., Cooper, C. L., \& Cartwright, S. (2004). A Shortened Stress Evaluation Tool (ASSET). Stress and Health Journal, 189-201.

Fisher, G. G., Bulger, C. A., \& Smith, C. S. (2009). Beyond Work and Family: A Measure of Work/Nonwork Interference and Enhancement. Journal of Occupational Health Psychology, 441-456.

Fisher, N., Lyonette, C., Barnes, S.-A., \& Newell, K. (2015). TIN 2.050 Current understanding and attitudes to work-life balance in the UK Armed Forces. Farnborough: Defence Human Capability Sciences \& technology Centre (DHCSTC).

Fisher-McAuley, G., Stanton, J., Jolton, J. A., \& Gavin, J. (2003). Modeling the relationship between work-life balance and organizational outcomes. Annual Conference of the Society for IndustrialOrganisational Psychology (pp. 1-26). Orlando, FL: Institute for Social Research, University of Michigan.
Grant-Vallone, E. and Donaldson, S., (2010). Consequences of work-family conflict on employee well-being over time. International Journal of Work, Health \& Organisations, 15(3). 214-226.

Greenhouse, J. H., Ziegert, J. C., \& Allen, T. D. (2011). When family-supportive supervision matters: Relations between multiple sources of support and workfamily balance. Journal of Vocational Behavior, 80, 266-275

Grzywacz, J. G., \& Carlson, D. (2007, November 4). Conceptualizing Work-Family Balance: Implications for Practice and Research. Advances in Developing Human Resources, pp. 455-471.

Handayani, A., Afiatin, T., Adiati, M.G. (2015). Studi eksplorasi makna keseimbangan kerja keluarga pada ibu bekerja. Prosiding Seminar Psikologi \& Kemanusiaan 2015 Psychology Forum UMM. ISBN: 978-979796-324-8

Helmle, J. R. (2010). Copreneur and communication: Work-family balance in married couple's family businesses. Unpublished doctoral dissertation. California: University of California.

Jefferies, J. (2001a). Quality of life in the Canadian Forces: Qualitative analysis of the QoL questionnaire for $C F$ members. Sponsor Research Report 01-11. Ottawa: Director Human Resources Research and Evaluation.

Kartini, R., Zakiyah, \& Narulita, S. (2018). Hubungan Mekanisme Koping Terhadap Tingkat Stres Prajurit TNI Angkatan Darat. Jurnal Kesehatan. 23-34.

Kavanagh, J. (2005). Stress and performance: A review of the literature and its applicability to the military. Santa Monica: RAND Corporation.

Kotera, Y., Green, P. \& Sheffield, D. (2019). Work-life balance of UK construction workers: Relationship with mental health. Construction Management and Economics

Lacey, M. (2005, May 23). New York Times. Retrieved from New York Times: https://www.nytimes.com/2005/05/23/wor ld/africa/un-forces-using-tougher-tacticsto-secure-peace.html

Lolombulan, H. I. (2015). Kajian Yuridis UndangUndang Nomor 34 Tahun 2004 Tentang Tentara Nasional Indonesia Terhadap 
Kedudukan Dan Tugas Tni Dalam Pemberantasan Terorisme di Indonesia. Lex et Societatis Journal. 92-100

Morganson, V. J., Litano, M. L., \& O’Neill, S. K. (2014). Promoting Work-Family Balance Through Positive Psychology : A Practical Review of the Literature. The Psychologist-Manager Journal of American Psychological Association, 221-244 .

Miles, B. M. \& Huberman, M. (1992). Analisis Data Kualitatif Buku Sumber Tentang Metode-metode Baru. Jakarta: UIP.

Parkes, L. P., \& Langford, P. H. (2008). Work-Life Balance or Work-Life Alignment? A test of the importance of work-life balance for employee engagement and intention to stay in organisations. Journal of Management \& Organization, 267-284.

Poerwandari, E.K. (2001). Pendekatan Kualitatif Untuk Penelitian Perilaku Manusia. Jakarta: LPSP3 UI.

Pickering, D. I. (2006). The relationship between work-life conflict/work-life balance and operational effectiveness in the Canadian Forces. Toronto: Defence R\&D Canada.

Pratiwi, A. (2019). Pengaruh Work-Life Balance terhadap Work Engagement pada TNI yang Bekerja di Dinas Psikologi Angkatan Udara. Jakarta: UNJ.

Schabracq, Winnubst, \& Cooper. (2003). The handbook of work and health psychology. England: John Wiley \& Sons.
Society, I. (2001). Managing best practice. Occupational Stress No. 83, 4-23.

Sugiyono. (2009). Metode Penelitian Kuantitatif, Kualitatif dan $R \& D$. Bandung: Alfabeta.

Thomas, J. L., \& Castro, C. A. (2003). Organizational behavior and the U.S. Peacekeeper. In T. W. Britt, \& A. B. Adler, The psychology of the peacekeeper: Lesson from the field (pp. 127-146). London: Praeger.

Valcour, M. (2007). Work-based resources as moderators of the relationship between work hours and satisfaction with workfamily balance. Journal of applied psychology, 92(6), 1512.

Wierda-Boer, H. H., Gerris, J. R. M., \& Vermulest, A. (2008). Adaptive strategies, gender ideology, and work-family balance among Dutch dual earners. Journal of Marriage and the Family, 70(4), 1004-1014.

Yamasitha, H. (2008). 'Impartial' Use of Force in United Nations. International Peacekeeping, 615-630.

Yang, J.W., Suh, C., Lee, C.K., and Son, B.C., (2018). The work-life balance and psychosocial well-being of South Korean workers. Annals of Occupational and Environmental Medicine, 30(38), doi: 10.1186/s40557-018-0250-z 